\title{
The Use of Speech Level in Socio Cultural Perspetive of Tapal Kuda Madurese Ethnic Society
}

\author{
Akhmad Haryono*, Bambang Wibisono \\ University of Jember, Jl. Kalimantan 37, Tegalboto Jember, East Java, Indonesia
}

A B S T R A C T

\begin{abstract}
Madurese society at Tapal Kuda regions has a unique cultural tradition because of cultural acculturation with other ethnics. This research aims at describing the speech level use in socio cultural perspective of Madurese ethnic society in Tapal Kuda regions. The method used to reach the research aims is a qualitative method with an ethnographic approach. The data were collected through participatory and non-participatory observations, interviews, note-taking, and recording. The data collected were transcribed into the written data and then analysed with pragmatic theory. The use of BM with E-E, Ng-E, and Ė-B variation in the perspective of Madurese ethnic in Tapal Kuda is as the politeness implementation form and formal relationship among speech participants, whereas variation of BM E-I (ngoko: Javanese) in family is used to keep intimacy and closed relationship between parents and children in order not to be too formal.
\end{abstract}

A R T I C L E I N F O

\author{
Paper type: \\ Research Article
}

Article history:

Received: 5 October 2018

Revised: 19 October 2018

Accepted: 24 October 2018

Keywords:

- Madurese etnic

- politeness

- speech level

- Tapal Kuda

\section{Introduction}

Madurese ethnic group at Tapal Kuda regions has a unique tradition. The uniqueness constitutes the environmental impact of multicultural and multilingual society. On the one hand they still keep their ancestor's culture, on the other hand they aculturate with other ethnics. Marriage is one of the ways which most frequently becomes a bridge of cultural acculturation.

Ethnic diversity has also created diversity (multilingual society). Multilingual societies within a country often cause problems or contain potential inter-ethnic language problems or at least cause certain consequences related to language use and cultural understanding. Language diversity brings problems for individuals and groups of individuals (especially for minorities of language users), government, and education (Haryono, 2013). Therefore, in a multilingual society it is very important for every member of the speech community to know the use of language elements used by other speech community so as not to cause wrong perception, especially for members of the community involved ethnic intermarriage.

In general, in a language there are certain ways to determine the difference in attitude of the relationship between the speaker and the spoken partner in the speech. The attitude is usually very varied and is determined by the assumption about the social level of the speech participants. For example, when a speaker speaks with a person who needs to be respected, then surely the speaker will use a speech code that has the meaning of respect. Similarly, when the speaker speaks to a person who does not need to be respected, the speaker will of course use a speech code that is not respected as well (Rahardi, 2001).

This phenomenon occurs because in the speech community there are members of certain groups who really need to be respected in speaking, but there are also in certain segments of society who do not need to get special

\footnotetext{
* Corresponding Author.

E-mail addresses: ahary ono.sastra@unej.ac.id (A. Haryono), bangwib@yahoo.co.id (B. Wibisono).
} 
respect, but more important to create closeness of relationships between speech participants.Therefore, the actual form of speech level in general can be divided into two, namely the form of respect that according to Poedjosoedarmo (1979) caused by the formality relationship of speech interparticipant and the usual form to maintain and create intimate relationships between speeech participants. Factors that cause the existence of two kinds of speech levels that turned out are really varied and different from one community to another one. A person in a society will be respected or perhaps disrespected because of hid/her body shape and condition, economic power, social status, strength, and political influence, kinship, age, gender, psychical condition, and so on. A person also becomes familiar or unfamiliar, near or far away due to a kinship relationship (eg, parent - child, in - law - in - law), friendship, business or job relationship, and so on.

Based on the above explanation, BM speech level and its use in social interaction of Madurese society can be described as in the table 1 .

Table 1. BM Speech Level

\begin{tabular}{|c|c|c|c|c|c|}
\hline \multirow{2}{*}{ Speech Level/ Variaton } & \multirow{2}{*}{$\begin{array}{l}\text { Participant } \\
\text { Relationship }\end{array}$} & \multirow[t]{2}{*}{ Use } & \multicolumn{3}{|c|}{ Examples of Word Use } \\
\hline & & & $\mathrm{I}$ & You & Yes \\
\hline $\begin{array}{l}\text { enjấ'-iyâa } \\
(\mathrm{E}-\mathrm{I})\end{array}$ & $\begin{array}{l}\text { the same age or the } \\
\text { speaker is older; } \\
\text { very close }\end{array}$ & $\begin{array}{l}\text { with close friend; } \\
\text { parents to children }\end{array}$ & sèngko' & bâ'na & iyâa \\
\hline $\begin{array}{l}\text { engghi-enten } \\
\text { (E-E) }\end{array}$ & $\begin{array}{l}\text { the speaker is } \\
\text { younger with not so } \\
\text { far social status }\end{array}$ & $\begin{array}{l}\text { same adult who just } \\
\text { knew, to parents } \\
\text { sesamadewasa }\end{array}$ & kaulâ & sampèyan & engghi \\
\hline $\begin{array}{l}\text { èngghi-bhunten } \\
\text { (È-B) }\end{array}$ & $\begin{array}{l}\text { the speaker is } \\
\text { younger with far } \\
\text { enough social } \\
\text { status; often in } \\
\text { interaction }\end{array}$ & $\begin{array}{l}\text { to superior, to parents in } \\
\text { law }\end{array}$ & bhâdhânkaulâ & panjhənnengngan & èngghi \\
\hline $\begin{array}{l}\text { bhâsaalos } \\
\text { (BAl) }\end{array}$ & $\begin{array}{l}\text { the speaker with } \\
\text { very far social } \\
\text { status; never in } \\
\text { interaction }\end{array}$ & to kiyai; to lord & $\begin{array}{l}\text { dâlam/ } \\
\text { abdhina }\end{array}$ & Ajunan, padhâna & dhâləm \\
\hline $\begin{array}{l}\text { engghè-enten } \\
\text { (Eg-E) }\end{array}$ & $\begin{array}{l}\text { the speaker is older; } \\
\text { often in interaction }\end{array}$ & $\begin{array}{l}\text { parents in law to son/ } \\
\text { daughter in law; } \\
\text { younger neighbor }\end{array}$ & bulâ & Dhika & engghe \\
\hline $\begin{array}{l}\text { bhâsaMalaju(ragamkota) } \\
\text { (BMlj) }\end{array}$ & $\begin{array}{l}\text { rather close, no } \\
\text { family relationship }\end{array}$ & $\begin{array}{l}\text { school/office mate, } \\
\text { other ethnics }\end{array}$ & saya & Situ & iya \\
\hline
\end{tabular}

The description of table 1 shows the variation of language that is based on the relationship between speech participants. Based on these reasons, the question is how is the use of speech level in social cultural perspective of Madurese ethnic community in Tapal Kuda regions?

In the event of communication, the speech participants do not not only respect the principles of cooperation as proposed by Grice (1975) but also must pay attention to the principles of decency (Nadar, 2009). Leech (1983), Wijana (2010), and Nadar (2009) stated that in an interaction the principals need another principle, i.e politeness principle. Principles of politeness can be specified into maxims, ie wisdom maxim (tact maxim), generosity maxim, acceptance maxim, and humility maxim sympathy maxim).

It relates to the use of speech levels as a form of implementation of the maxim of humility that requires every participant to maximize self-disrespect and minimize self-respect. The use of speech levels in communication events is an attempt to maximize respect for others and minimize self-respect. Thus, it can be said that this maxim of humility supports the other maxims, especially the maxim of sympathy which requires each participant to maximize sympathy, and minimize the sense of antipathy to his or her opponent

According to Yule (1996) and Nadar (2009), the underlying theory of language decency strategy is the concept of face. Brown \& Lavinson (1978), Huang (2008), Nadar (2009) define the face as a general self-image that is owned by every citizen who includes two interrelated aspects of the negative face which is the desire of everyone in the region, the right of the individual, the right to be free from disturbance that is freedom of action and freedom from the obligation to do something, and a positive face that is a consistent self-image or personality that belongs to an interacting citizen (including the desire for a positive image to be recognized and appreciated. 
According to Levinson (1985), politeness involves our consciousness to show that it does not threaten the faces of others, and it refers to our image in public. Furthermore, Sukarno (2010) states that politeness is a way of managing 'face' in various ways so that the said partner does not lose the 'face' or how to save his face.For that, indirect language form is often used to keep it. There are two aspects to our self-image that is positive face and negative face. The positive face refers to everyone's desire that what he wants is liked at least by some and the negative face refers to the wishes of a member of society whose actions do not need to pay attention to the wishes of others

Among the six politeness criteria of Leech (1983), the following six points are crucial: (1) Tact-maxim (in imposition and commissiveness): minimizing costs for others; maximizing benefits for others; (2) maxim of generosity (in terms of implicit and commissive): minimizing benefits for oneself, maximize self-expense;(3) maxim of praise (in expressive and assertive): minimizing costs for others, maximizing praise for others;(4) maxim of humility (in expressive and assertive): minimizing praise of self, maximize praise for others;(5) maxim of agreement (in assertiveness): minimizing disputes between self and others, maximizing agreement between self and others; (6) maximal sympathy (in assertiveness): minimizing antipathy between self and others maximizing sympathy between self and others.

In daily life, we are aware of polite and impolite behavior. For example, offering a seat for old people in a bus is considered as a polite behavior, and interrupting when someone is speaking is considered as an impolite behavior; greeting someone at first meeting in the morning is polite, and standing to take a dish you need at dining table is impolite. Politeness can therefore be firstly considered as observable social (Huang, 2008).

In terms of analysis, politeness is then easily understood by recognizing that with polite behavior we have final purpose. For example, the very common case is that every time we want someone to help us, we have to ask for a request politely.

Greeting someone, shaking hand, sending a birthday card, giving a present, or tapping the shoulder shows good feeling, friendliness, or intention to keep harmonious relation to someone. In general, we behave decently to show our desire to start a friendship relationship with someone, or to defend it if it already exists, or to fix it if it is threatened for some reason. To maintain good and harmonious interpersonal relationships required by human communities, politeness serves as a ready-to-deliver tool for achieving goals.

Politeness can also be regarded as a restraint other than as a means to an end, a kind of social norm imposed by a community convention of its member. Sometimes we feel that we should be polite to show that we are civilized and nurtured in such a way that we know what to do to meet commonly recognized social standards so that we will not be accused of being rude or impolite. To be polite, we must be tolerant. In certain circumstances, to meet certain standards, we must refrain from doing certain things that we will personally do to others (Huang, 2008).

Thus, politeness can at once be understood as a social phenomenon, a means to achieve good interpersonal relationships, and norms laid down by social conventions. It then becomes phenomenal, instrumental, and normative for the universe.

In many ways, politeness is universal. This can be observed as a phenomenon in all cultures; it is used by different language speakers as a means to achieve the goal and it is recognized as the norm in all societies. Although its universality is a manifestation of real politensess, the ways to manifest politeness, and the standards of judgment differ in different cultures. Such distinctions must be traced back to the origin of the notion of politeness in different cultures (Huang, 2008). This is in line with the opinion of Haryono (2015) politeness is a universal concept possessed by any language and culture in the world. This means that every language has the principles of politeness as a strategy of communication to achieve certain goals.

\section{Research Methods}

The method used in this research a qualitative method with an ethnographic approach. The data were collected through participatory and non-participatory observations, interviews, note-taking, and recording with sound and video recording tool to anticipate the limitations of researchers in listening. Recording is also used to document things that are considered important not to be missed.

The data obtained through the recorder were transcribed to the written data then classified according to the problem to be answered. The classified data were analyzed descriptively by sociolinguistic method and discourse analysis method with pragmatic concept.The sociolinguistic method is used to reveal the use of language in the socio-cultural context of ethnic Madurese in Tapal Kuda regions. Discourse analysis methods 
with the help of pragmatic concepts (see Yule, 1996) were used to analyze the use of politeness in the context of speech that occurs in the speech community.

\section{Result and Discussion}

\subsection{Speech Level in Family Domain}

Based on the data collected, the use of speech level in the family domain of Madurese ethnic (ME) in Tapal Kuda regions includes communication between husband and wife, communication with parents, and parents inlaws. The variety of languages used in the family is Madurese language (ML) variety ênjâ'-iyâ ( $\hat{\mathrm{E}}-\mathrm{I})$, èngghi-

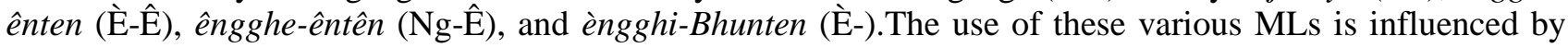
social status, age differences, gender, and the proximity or formality of interpersonal relationships. The use of speech level can be described as follows.

\subsection{Language Variety Used by Husband-Wife}

From the research that has been done can be described that the variety of language used by husband and wife of marriage at the early age in the family realm (when communicating daily at home) there are two kinds, namely ML of Ê-I and $\hat{E}-E$ variety.

Language variation commonly used by husband and wife who come from ordinary family or the same santri family but with ordinary social status is Madurese variation of Ê-I.The use of Madurese variation ngoko or harsh in interwoman-wife communication appears on the following conversation quotation.

Context: the conversation was done by Zainal and his wife Aminah (A). The conversation outside the room, on the terrace of Zainal's house, took place late in the afternoon, on Sunday, at about 4:15 pm. The conversation happened after someone had just offered a motorcycle to Zainal (Z). Conversation topic was about motorcycle prices.

Data 1: The use of speech level Ê-I

A: Mènta’ bârâmpa sêpédana Kang? Sêpédana?

(How much is your motorbike? Motorbike?)

Z: Têlo juta sêtênga, dâ' remma lè, 'èkala'a?

(Three and a half millions, what do you think? You want to buy?)

A: Yâ la, apa caên bâen.

(Yeah, it's up to you)

From the quotation of the conversation it can be described that the language used by husband $(\mathrm{Z})$ when communicating with the wife (A) is ML variation of $\hat{\mathrm{E}}-\mathrm{I}$ or ngoko variation. This is evident from the vocabulary used in the conversation of data 1 . The words used in the conversation between $\mathrm{Z}$ and A are ML vocabulary of Ê-I.

ML of ngoko variationthey used because both come from ordinary family, not from kyai or santri family. The use of Ngoko speech level is due to the lack of a formality relationship between the two and indicates the intimacy and closeness of the relationship.

If the husband comes from a kyai family and the wife comes from an ordinary family, the husband usually uses ngoko variation or rough variation in communicating with his wife, while the wife uses ML of krama variation of (E-E) or ML variation of E-B.The use of ML ngoko variation and $\hat{E}-\mathrm{E}$ or $\grave{\mathrm{E}}-\mathrm{B}$ in husband and wife communication appears in the following data quoted below.

Context: Conversation between husband, Abdul Syukur (A) and his wife Khatimah (K). It took place outside the room, on the edge of the rice fields, in the morning on Sunday at 08.00. The conversation happened when Abdul Syukur and his wife were resting (on the sidelines of plowing the land). 
Data 2: The use of ML ngoko variation of Ê-E, and È-B
A: èpadâ' remma, sabhrânga?
(What are you doing with your cassava?)
K: Nèka ghi' èghuring. Sakejjhâ aghi'ampon massa' (It's being fried, it finishes soon).

\section{A: iyaâ marèbadâ'a tamoy}
(yeah, there will a guwat immediately).

From the quotation of the conversation, it can be described that the language used by husband (A) when communicating with wife $(\mathrm{K})$ is ML of $\hat{E}-\mathrm{I}$ variation or ngoko variation, while that used by $\mathrm{K}$ is $\hat{\mathrm{E}}-\mathrm{E}$ and $\grave{\mathrm{E}}-$ $\mathrm{B}$. The use of ML in $\hat{\mathrm{E}}-\mathrm{E}$ variation by $\mathrm{K}$ appears in the word nèka ('this') and enten ('no') which is the vocabulary of ML code of $\hat{E}-E$ variation. Ampon (ready), èngghi ('yes') is the implementation of the use of ML È-B variation because the two vocabularies include MLof Ė-B code.The use of various ML of $\hat{E}-E$ and $\grave{E}-B$ by K is a form of the use of politeness principle because of the formality relation of both, because the kiai's son in the ME perspective belongs to the category of people who are considered as the respectable teachers. If the husband and wife are both from the kiai family or the husband's family of the common people, but he once lived in the pesantren, while the wife'sfamily is from kiaifamily, they tend to choose to use the various kinds of manners in communicating. The use of this variety by both husband and wife appears in the following quote.

Context: Conversation between husband named Syahri (S) and wife named Hamidah $(\mathrm{H})$. The conversation took place outside the room, on the edge of the rice fields, in the morning on Friday, at 07.00 WIB. The conversation happened when $\mathrm{S}$ and $\mathrm{H}$ (his wife) were looking at corn crops in their fields.

Data 3:

\section{S: Ètamenènna jhâgung nèka Ka'? (Corn will be planted?)}

$\mathrm{H}: \quad$ Engghi lè', etamenenna jhâgung. (Yes, corn will be planted)

S: Ma'lè bâdâ èarep telasan. (in order to be the expected, in holiday )

\section{H: Sà̀ pas èbhâdi marning. (Good, it can be for "marning" = kind of meal from corn)}

The quotation of the conversation indicates that the language variant used by the husband (S) when communicating with the wife $(\mathrm{H})$ is the ML variation of $\hat{\mathrm{E}}-\mathrm{E}$ or the variation of krama madya.The use of ML variation of $\hat{E}-E$ by $\mathrm{S}$ and $\mathrm{H}$ appears in the use of words such as êngghi (yes), Saè (good) and èbhâdi (to be made) which are the codes of $\hat{E}-E$ language code.The use of this language variation of $\hat{E}-E$ is more due to the similarity of both degrees and to reduce the level of formalities both to be more familiar in the household

From the exposure it can be abstracted that language variation which is commonly used by husband and wife who come from ordinary family or family of the same santri but with ordinary social status is Madura language variation of Ê-I.If the husband comes from a kyai family and the wife comes from an ordinary family, the husband usually usesML variation of ngoko or regular variation in communicating with the wife, while the wife uses ML variation of krama madya and kramaof $\hat{E}-\mathrm{E}$ and $\grave{\mathrm{E}}-\mathrm{B}$ variations.If the husband and wife are from kiai family or the husband's family from the common people, but the husband has ever lived in the pesantren, while the wife's family is from among the kiai family, they tend to choose the ML variation of krama madya (Ê-E variation). 


\subsection{Variations Used by Children to Parents}

Based on the results of the research, it can be described that in communicating with the parents the ME community in Tapal Kuda regions uses ML variations of $\hat{E}-\mathrm{I}, \hat{\mathrm{E}}-\mathrm{E}$, and $\grave{\mathrm{E}}-\mathrm{B}$. The use of $\hat{\mathrm{E}}-\mathrm{I}$ variation in communicating with parents can be seen in the following data.

Context: A chat between a son named Abd. Rochim (R) and his mother Siti Romlah (S). The nature of interaction is dyadic. The conversation took place at Romlah's house, in the afternoon, when the informant told him about his college and his sister's circumstances.

Data 4: The Use of Ê-I variation between a parent and a son

(R): $M a^{\prime}$. Engko' $M a^{\prime}$ !

(Mother, I am coming, Mother)

(S): Iyâ, padâBârâskabbhi cong? Êngko' matoro'aalè 'ênyâ, patêpa'aghi mon sala. Bâremmaano, AjiAlè'en?

(Yes, are you fine? I leave your younger brother her, ok. What about Aji, your younger brother?)

(R): Iyâ Ma', bâ'na jhâ talèbât mèkkèrè Aji, na'-kana' la rajâ.

(Ok Mother, Don't think more about Aji. He's already grown)

(S): Bâremmaano, mbuênIin!

(How is Iin's mother)

(R): Alhamdulillah! mbuên Iin sehat Ma'. (Alhamdulillah! She is fine, Mother)

In the conversation on the data 4 it looks that the words used by $\mathrm{R}$ in communicating with the mother (S) are the words belonging to ML variation of ngoko ( $\hat{\mathrm{E}}-\mathrm{I})$, not the words of krama variation. For example, it appears in the use of the word: êngko '(I), dâtêng' (coming), and iyâ (yes) in the speech which shows Ê-I variation. The use of Ê-I variation (ngoko) because of the closeness of the relationship between mother and child, even in nonsantri Madurese society if using the subtle language) is considered far-interrelated and can reduce intimacy and closeness with parents. Therefore, Madurese people in this group do not allow using it.

Because the words used by $\mathrm{R}$ and $\mathrm{S}$ in the conversation belong ngoko variation, it can be said that $\mathrm{R}$ in communicating with the mother uses ML variation of ngoko. Furthermore, the use of the E$-E$ variation in communicating with parents appears in the following quotation of the conversation.

Context: a conversation between Dul Halim with Suep (father) and fatimah (mother). The nature is polyadic interactions, that is, there are three people involved in the chat, namely Fatimah (F), Dul Halim (D), and Suep (S). The conversation took place at F's home, late afternoon, about 16.30

Data 5:

(1) D: Kulânyo'onseporrasé bênya' ka sampéyan. Kulâ pon tarèmma, èangkat dêdi pegawai, Pak! (I am sorry Father. Now I am accepted to be an officer)

(2) S: Duh! yâ Nak. bân êngko' bâ'ên épojhiyâ,mandar mogâ dâddiyâ orèng sé pojhur dunnya akhèrat! (Oh yamy son. I always pray, my you become a successful person here and after)

(3) F: Iyâ,Alhamdulillah... Bâ'ên la éangkat.Mandhâr tambâ'â muljâ bân bherkat!

(Ya. Alhamdulillah... you have been appointed. May you become more precious and blessing!)

(4) D: Aamiiin... Kêso'on!

(Ya, Amen... thanks) 
The quotation indicates that the words used by D in communicating with father and mother are mostly words belonging to the vocabulary of ML code of $\hat{E}-E$ variation. The use of this variety, among others, appears in speech (1) and (4). In these speeches M uses words, such as: kulâ('me'), nyo'on ('ask'), sampéyan ('you'), pon ('already'), and kaso'on ('thank you'). In ML the vocabulary is known as the words of ordinary respect.The use of E-E variation can be seen from the use of vocabulary in the chat, most of which are the vocabulary of $\hat{E}-E$ variation. The use of $\hat{E}-E$ variation as a form of politeness, but the level of formality is not too high because to the parents in the cultural perspective of Madurese society, as well as the need for the implementation of respect, an atmosphere of intimacy and closeness of relationships sre alaso required.In contrast, the father $(\mathrm{S})$ and mother (F) in communicating with the child (M) use $\hat{E}-I$ variation(ngoko: javanese).The use of $\hat{E}-I$ variation by the father and mother, among others, appears in speech number 5B and 5C.In the speech the father uses such words as, iyâa('yes'), êngko'(' I'), bê'ên' (you) and the like.The use of speech level $\hat{E}-\mathrm{I}$ is as a form of use of the role as a parent to the child to show closeness. Thus, based on data (5) above, it can be said that the parent in the cultural perspective of Madurese society in communicating with children uses E-I variation (ordinary variation: ngoko: Javanese), whereas the childin communicating with father using $\hat{E}-\mathrm{E}$ variation (karam madya: Javanese).

In relation to the use of È-B variation code-mixing to E-E in communicating with the parent, whereas the parent uses Ê-I language variants, it appears in the following quotation of the conversation.

Context: a chat between Lastri (L) as a daughter with Jumadi $(\mathrm{J})$ her father. The nature of the interaction between the two is dyadic. The chat event took place in the bedroom at J's home. It took place when J was ill, and sleeping on the bed. The chat took place atabout 16.30 to 16.35 . While participating to visit $\mathrm{J}$, the researcher recorded the chat between $\mathrm{L}$ and $\mathrm{J}$. In conducting the recording, the researcher was accompanied by a researcher assistant, namely L's husband.

Data 6:

\section{(A) J: Abhâjânga engko' bing! \\ (I want to pray, my daughter!)}

(B) L: Ł̀ngghi Pa', Èyatorè awudhu' dimin.

(Alright, father, Let's perform ablution first)

(C) J: iyâ na,

(Ok, daughter)

(D) L: Bapa' alongghu saos ghi!

(Father, just have a seat, right)

(E) J: iyâ na', ngala'aghi korsè!

(Ok daughter, take me a chair!)

(F) L: Èngghi ngèrèng pon pa'

(Alright, it's already, father)

The quotation indicates that the code vocabulary used by $\mathrm{L}$ (daughter) in communicating with $\mathrm{J}$ (the father) are the words belonging to È-B variation (krama variation: Javanese) and BM E-E variation (krama madya: Javanese, take it. The use of Ė-B and E-E variations can be seen from the code vocabulary used by L in communicating with J, which mostly contains Ė-B and E-E variations. The use of these variations appears in Lastri's speech using such wordsas Ėngghi (yes), Ėyatorè (let's), and dimin (formerly).Those words are words belonging to the vocabulary of ML code of the E-B variation.In communicating with the parents or parents in in-laws, the Madurese ethnic in Tapal Kuda regions uses E-E and E-B variations. This shows that L in communicating with $\mathrm{J}$ as an elderly person uses krama variation.

Based on the results of research that has been done, it can be described that the use of speech level as a form of the implementation of politeness principles in the EM family in Tapal Kuda regions is influenced by several variables, among others:(1) social; (2) psychological; and (3) Madurese ethnic culture. Social variables that affect communication patterns among the EM community in Tapal Kuda regions in communication are: (a) 
differences in social status; (b) age differences; and (c) position and role in the family and in society. Psychological variables that determine the use of speech level, among others, are the closeness of relationships, and familiarity with parents while the cultural variable that affects the use of speech level is the level of relationship formalism that affects the feeling of respect and familiar. When there is a violation of these variables then the wrong perception arises, so it can cause a gap in communication that results in a wrong perception of cultural understanding behind the language.

\section{Conclusion}

From the description that has been put forward can be concluded that the Madurese ethnics in Tapal Kuda regions (Jember, Bondowoso, probolinggo, and Situbondo) has culturally acculturated through interethnic marriage. This is driven by the fact that they live in a pluralistic society composed of various ethnicities. However, the politeness, respectfulness, and religious traditions and cultures that characterize the ethnic Madurese are retained.

Communication with the living companion of the same member of Madurese ethnic in Tapal Kuda regions uses ML which constitutes ngoko variation (E-I) and karma variation (E-E and E-B). They use ngoko variation if they both come from ordinary families, as a form of close relationship and intimacy.If they are from a santri family they tend to use E-E and Ė-B variations as the use of politeness and the practice of religious values.

In communicating with the parents (father and mother), some Madurese ethnic groups in Tapal Kuda regions use E-I variation and some use E-E and E-B variations. The use of E-I variation is commonly used by those with ordinary or low social status, whereas those with medium and high social status (nobility and santri group) tend to use the E-E or È-B variaton.

In communicating with the parents in-laws of Madura ethnic group members in Tapal Kuda regions, the children always use the E-E and È-B variations, while the parents in-laws use E-I and Ng-E languages.The use of E-I variation is commonly used by the parents in-laws to show the closeness of the relationship because the son/daughter-in-law is also considered to be thier children. The use of Eg-E variation is commonly used by the parents in-laws with son/daughter-in-law with santri background.

The use of E-E, Ng-E, and È-B variations (Krama madya and Krama inggil: Javanese) in the social cultural perspective of Madurese ethnic communities in Tapal Kuda regions is as a form of politeness implementation and a formal relationship between speech participants, while E-I variation (Ngoko: Javanese) among families is to maintain intimacy and closeness of the relationship between parents and children so as not to be too formal.

\section{Acknowledgement}

I would like to express my deepest appreciation to DRPM directorwho has provided this Stranas/Applied research grant to produce an out put of this scientific article. Furthermore, I would also like to acknowledge with much appreciation the crucial role of Rector of University of Jember, Chairman of LP2M, Dean of Faculty of Cultural Science, and Head of English Literature Department, who have me given support so that the research implementation of this article can run smoothly.

\section{References}

Brown, P., \& Lavinson, S. (1978). Universal in language usage: politeness phenomene. In E. Goody (Ed.), Question and politeness: Strategies in social interaction. Cambridge: Cambridge University Press.

Grice, H. (1975). Logic and Conversation. In Cole, \& Morgen, Radical Pragmatics (pp. 41-58). New York: Akademic Press.

Haryono, A. (2013). Keragaman bahasa dan budaya: Problematika dan perannya alam komunikasi antar udaya. International Seminar Lingusitics Studies in several Perspective. Yogyakarta: FIB UGM.

Haryono, A. (2015). Etnografi Komunikasi: Konsep, teori, dan contoh peneliian pola komunikasi. Jember: UPT Penerbitan Universitas Jember.

Haryono, A. (2018). Communication patterns among kiais of Nahdlatul Ulama in the Madurese ethnic group. Indonesian Journal of Applied Linguistic (IJAL), VII(3), 714-726.

Huang, Y. (2008). Politeness principle in cross-culture communication. English Language Teaching (CCSE), I(1), 96-101. 
Leech, G. (1983). The principle of Pragmatics. (O. MDD, Trans.) Jakarta: UI Press.

Levinson, S. (1985). Pragmatics. Londnon: Cambridge University Press.

Nadar, F. (2009). Pragmatik \& penelitian Pragmatik. Yogyakarta: Graha Ilmu.

Poedjosoedarmo, S. (1979). Tingkat tutur bahasa Jawa. Jakarta: DEPDIKBUD.

Rahardi, K. (2001). Sosiolinguistik, kode dan alih kode. Yogyakarta: Pustaka Pelajar Offset.

Sofyan, A. (2016). Bahasa madura dialek Sumenep. Yogyakarta: Galang Press.

Sukarno. (2010). The reflection of the Javanese cultural concepts in the politeness of Javanese. Kata: $a$ Biannual Publication on Study of Language and Literature, XII(1), 59-71.

Wijana, I. (2010). Pengantar semantik bahasa Indonesia. Yogyakarta: Graduate school of UGM in collaboration with Pustaka Pelajar.

Yule, G. (1996). Pragmatics. Hongkong: Oxford University Press. 